\title{
Derivational neologisms as synonyms of regular derivatives
}

\section{Derivatīvie neoloğismi kā sistēmisko atvasinājumu sinonìmi}

\author{
Jolanta Vaskelienè \\ Šiauliai University \\ P. Višinskis Street 38, Šiauliai, Lithuania \\ E- mail:jolanta.vaskeliene@su.lt
}

The Lithuanian language constantly acquires neologisms: some are used to name new things, while others are used as synonyms of common words. The Lithuanian language is rich in derivational synonyms, i. e. cognate derivatives having different word formation formants and similar lexical meaning. The rows of derivational synonyms are not static: they disappear or become shorter with the loss of a derivative or when the meaning of the derivative disappears; they are formed or become longer when a neologism or a new meaning of the derivative appear. The research material includes the derivational neologisms found in the prose texts of Lithuanian authors that are used as the synonyms of regular derivatives. The article discusses the newly formed or prolonged rows of derivational synonyms: the formation of neologisms, usage tendencies, substitution possibilities are analysed.

Keywords: derivational neologism; derivative; compound; derivational synonyms; row of synonyms.

Lexicon is the most changing component of the language. The demand for new words most is often fulfilled by borrowing, translating, and creating new words using the existing word formation patterns. The latter way is the most essential and efficient. The Lithuanian language constantly acquires derivational neologisms, i. e. new words that are formed under the usual word formation patters (Urbutis 2009, 37; Jakaitiene 2010, 205-208; see also Wales 1989, 317; Salys 1979; Mikelionienė 2002; Bauer 2004; Miliūnaitė 2015). Some neologisms do not survive in the language, while others eventually become a part of the active lexicon. „In science and technology, in administrative and informative spheres, as also in conversational use, neologisms generally have a denotative role, while in literary and some informative texts the use of neologisms is bound up with artistic aims" (Rozenbergs, 2004, 155; see also Pikčilingis 1975, 29-32; Kniūkšta 1981; Župerka 2012, 68-69). ${ }^{1}$ Thus, some neologisms are used to name new things and notions,

1 Expressive neologisms are also called stylistic, occasional neologisms, etc. In this research derivational neologisms are considered to be derivatives not included in Lietuviu kalbos žodynas (Dictionary of the Lithuanian Language), Dabartines lietuviu kalbos žodynas (Dictionary of Modern Lithuanian), Bendrinès lietuviu kalbos žodynas (Dictionary of Standard Lithuanian), Lietuviu kalbos žodyno papildymu kartoteka (Supplement Catalogue of the Dictionary of the Lithuanian Language), Lietuvių kalbos naujažodžiu duomenynas (Database of Lithuanian Neologisms). 
while others are used as synonyms of regular units of the Lithuanian lexicon. A particularly great number of derivational neologisms are used in the texts of many Lithuanian authors (see Vaskelienè 2010; 2012; 2017). Having a lot of word formation means the Lithuanian language is rich in derivational synonyms, i. e. cognate derivatives having different word formation formants, identical or similar lexical meaning and identical derivational meaning (Vaskeliené 2000). It should be noted that the rows of derivational synonyms are not static: they disappear or become shorter with the disappearance of a derivative or the meaning of the derivative; they are formed or become longer when a neologism or the new meaning of the derivative appears. The aim of the present article is to discuss the newlyformed (or prolonged) rows of derivational synonyms including the derivational neologisms. The research material was drawn from the prose texts of Lithuanian authors $^{2}$ (see Sources) that are used as synonyms of the cognate regular derivatives. The methods of analysis, interpretation and substitution were employed.

It should be noted that the Lithuanian language (regardless of the nature of the text) mainly forms noun and adjective neologisms (adverb and verb neologisms are not so common). Noun neologisms formed with the help of suffixes and inflexions are to be allocated to various formation categories but abstract lexical units are most common. The row of derivational synonyms often contains the derivatives of productive formation categories. For example, according to the Dictionary of Modern Lithuanian, the rows of verb abstract derivational synonyms most often include the derivatives with the suffixes -imas / -ymas, -esys, -tis, -ulys, -smas, endings $-a$, -is (-ys), and the most abundant groups of derivational synonyms consist of common-root derivatives with the suffixes -imas / -ymas and -tis, -imas / -ymas and -esys, -imas / -ymas and -ulys (Vaskelienè 2000, 42-72). Verb abstracts are considered to be the derivational neologisms of the suffix -tis, for example:

(1) atitver-t-is (: atitverti) 'fence', 'dividing wall', atpirk-t-is (: atpirkti) 'redemption', 'atonement', igaub-t-is (: igaubti) 'concave','concavity', išgaub-t-is (: išgaubti) 'camber', sukaup-t-is (: susikaupti) 'concentration', 'introversion', sutelk-t-is (: susitelkti) 'concentration', the derivatives of the suffix -esys, for example:

(2) iešk-es-ys (: ieškoti) 'search', plast-es-ys (: plastèti) 'flutter', sklid-es-ys (: sklisti) 'spread', švogžd-es-ys (: švogžti) 'wheeze', 'snort', tyl-es-ys (: tylèti) 'silence',

the derivatives of not very productive suffix -la, for example:

(3) speng-l-a (: spengti) 'tingle', sting-l-a (: stingti) 'rigidness', 'stiffness', the derivatives of the suffixes -smas, -atis, inflection -is, for example:

(4) gel-sm-as (: gelti) 'pain, ache', skaud-at-is (: skaudèti) 'pain', ịskil-is (: iskilti) 'crack'.

These derivational neologisms are used in the similar meaning as regular derivatives, so new rows of derivational synonyms are formed:

2 Prose texts are chosen because in poetry neologisms can be used for rhyme and rhythm (which is not required in prose texts). 
(5) plastesys*3 - plastèjimas ('flutter'), sklidesys* - sklidimas ('spread'), švogždesys* - švogždimas ('wheeze','snort'), sukauptis* - su(si)kaupimas ('concentration', 'introversion'), ịskilis* - iskilimas ('crack'), or the existing rows of derivational synonyms become longer:

(6) atitvertis* - atitvérimas - atatvaras ('fence', 'dividing wall'), atpirktis* atpirkimas - atpirkumas ('redemption', 'atonement'), igaubtis* - igaubimas igauba ('concave', 'concavity'), išgaubtis* - išgaubimas - išgauba ('camber'), sutelktis* - su(si)telkimas - santalka - santelkis ('concentration'), ieškesys* ieškojimas - ieškosena - ieškynès ('search'), tylesys* - tylejjimas - tyla ${ }^{4}$ tylone ('silence'), spengla* - spengimas - spengesys ('tingle'), stingla* stingulys - stingis ('rigidness', 'stiffness'), gelsmas* - gèlimas - gelsena gèla - gèlè ('pain, ache'), skaudatis* - skaudejimas - skausmas - skauda skaudas - skaudèsena - skaudesys - skaudis - skaudulys ('pain').

The closeness of meaning of the derivational synonyms can be best revealed by their usage. The derivatives which can be used interchangeably in the same context without changing its meaning are considered to be strictly synonymous. It should be noted that there are derivational synonyms which have the same, close or only a similar lexical meaning. That derivational neologisms and regular derivatives are synonymous is best shown by substitution: neologisms can be replaced by regular derivatives without changing essentially the sense of a word phrase or sentence, for example:

(7) Tačiau tasai nervingas plastesys yra apgaulingas... KE227 (cf. nervingas plastejimas)

'But that nervous flutter is deceptive...',

(8) Visus mūsu gudriausių užmačiu bei žabangų sklidesius ji [esybė] sugeria tobulai... K389 (cf. žabangu sklidimas)

'It (a being) absorbs perfectly all spreadings of our most cunning intents and snare ...',

(9) ...šįsyk balso beveik nepasigirdo, vien korètų plaučių švogždesys... K174 (cf. plaučiu šsogždimas)

'... this time the voice was not heard, only the snort of spongy lungs...',

(10) Ši elipsé neturi jokio ịskilio, ji absoliučiai uždara KE225 (cf. neturi iskilimo) 'This ellipse has not a crack, it is absolutely closed',

(11) ...blokada, sukelianti <..> klaikia atitverti nuo visu ir visko... K207 (cf. klaikus atitvérimas / atatvaras nuo visko)

'...the blockade causing $<\ldots>$ dreadful fence from everyone and everything...',

(12) Nes skausmas jau būtų atpirkties pradžia. O atpirkties čia nèr K155 (cf. atpirkimo / atpirkumo pradžia)

'Pain would be the beginning of redemption. And there's no redemption',

3 Neologisms are marked with an asterisk, derivational formants are highlighted, in word phrases or sentences neologisms are presented with the increased spacing between the letters, their synonyms are underlined.

4 Inflectional - $a$ derivative tyla could be based on the adjective tylus, $-i$, and the verb tylet $i$ (see Pakerys 1994, 239). 
(13) ...laiko igaubties akimirka... K449 (cf. igaubimo / igaubos akimirka)

'...the concavity moment of time...',

(14) ...grožis turi galios atitraukti žmogu nuo maldos ir sukaupties valandèliu K403 (cf. susikaupimo valandèle)

'...beauty has the power to withdraw a man of prayer and concentration hours',

(15) ...ausu bügneliai tuoj plyš - spenglos < ..> nebeatlaikę VP47 (cf. spengimo / spengesio nebeatlaikę)

'... eardrums will explode - being unable to resist the tingle',

(16) ...strèle staiga šauna ir skrieja - prakirsdama pilka nuovargio stingla... VP72 (cf. nuovargio stingulys / stingis)

'...the arrow suddenly shoots and swings - breaking the grey fatigue of stiffness...',

(17) ...prasminès pauzès išduos < ..> dvasinę büsena, skaudati K89 (cf. ǐ̌duos skausma / skaudejima / skauda / skaudesi)

'...meaningful pauses will betray $<\ldots>$ the spiritual state, pain'.

Sometimes a neologism and its synonym are used alongside, the repetition is used not only to make the text cohesive, but also it draws attention of the addressee:

(18) ...žodžiu šlamesị ima keisti vidine tyla, tylesys, iškvépimas K245

'...the whisper of words is being changed by the inner silence, the expiration'.

It should be noted that in the majority of cases the interchange of regular derivatives and derivational neologisms is possible, for example:

(19) Ir atpirkimo jis niekam nesiūlè T (cf. nesiūle atpirkties*) 'And he did not offer the redemption to anyone', ...lauke atpirkumo Izraelio LKŽe (cf. lauke Izraelio atpirkties*) 'he waited for Israel's redemption',

(20) Tai sužeisto erelio sparnu plastejjimas T (cf. sparnų plastesys*) 'It is the fluttering of wings of the wounded eagle',

(21) Man be skaudejimo trauke ta danti LKŽe (cf. trauke be skaudaties*) 'My tooth was pulled out without pain', be skaudos mire LKŽe (cf. be skaudaties* mirè) 'died without pain', Skausmas plèše galva... T (cf. skaudatis* plèš́ galva) 'The pain tore the head', priešinuosi $<\ldots>$ geliančiam skaudesiui $\mathrm{T}$ (priešinuosi skaudačiai*) 'I try to resist $<\ldots>$ the aching pain', Tai skaudis tos žaizdos! LKŽe (cf. skaudatis* žaizdos) 'The wounds are pain!', Užejo toks skaudulys, kad vos iškentè LKŽe (cf. užejo skaudatis*) 'And there come such pain, that he could hardly endure', etc.

So, it could be admitted that the derivatives of the newly formed synonym rows have a relative high degree of sameness: they have a similar (or identical) meaning and are used in a similar lexical environment.

The regular nominal abstract derivational synonym rows usually include the derivatives of the most productive word formation types -umas, $-y b \dot{e},-y s t \dot{e}$, -is (see Dabartinés lietuviu kalbos gramatika (Grammar of Modern Lithuanian), 


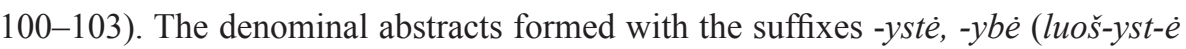

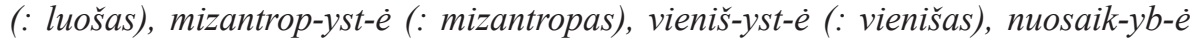
(: nuosaikus), pereinam-yb-e (: pereinamas) are also used as synonyms of regular, cognate derivatives, thus new pairs of derivational synonyms appear:

(22) pereinamyb $\dot{\boldsymbol{e}}^{*}$ - pereinamumas ('ability to cross', 'transit'),

(23) mizantropyste $\dot{\boldsymbol{e}}^{*}$ - mizantropija ('misanthropy')

or the existing derivational synonym rows become longer, for example:

(24) luošyste்* - luošumas - luošybè - luoša ('lameness'), vienišyste $\dot{\boldsymbol{e}}^{*}$ vienišumas - vienišuma - vienišybe ('loneliness'), nuosaikybe $\dot{e}^{*}$ nuosaikumas - nuosaika - nuosaike ('moderation').

All denominal abstracts could be replaced by regular derivatives and the meaning of the text would not be changed, for example:

(25) Tas pereinamybès tarpsnis, kai jau prabudęs, bet dar snūduriuoji P (cf. pereinamumo tarpsnis)

'The transitory phase, when you are already awake but still dozing',

(26) Mizantropysté - žmonijos pasaugojimas nuo pernelyg didelès ir karštos meilès LM35 (cf. mizantropija - žmonijos pasaugojimas)

'Misanthropy is keeping the mankind from the excessive and passionate love',

(27) Nuolankiai priimu luošystę, išdidžiai K392 (cf. priimu luošuma / luoša / luošybe)

'I humbly and proudly accept the lameness',

(28) Vienam tai verslo rūšsis, kitam - vienišyste KE161 (cf. kitam tai vienišumas / vienišuma / vienišybe)

'For one it is a type of business, for another it is loneliness'.

Sometimes a neologism is created by analogy with the adjacent regular derivative (see the abstract nuobodybe which is formed with the same suffix):

(29) ...maloni išimtis nuobodybès ir nuosaikybès jūroje DD87

'...pleasant exception in the sea of boredom and moderation'.

It should be noted that although in this case the neologism could be replaced by the regular derivative (nuosaikumo / nuosaikos / nuosaikés jüra), in the current Lithuanian language only the abstract nuosaikumas is commonly used: The Corpus of the Contemporary Lithuanian Language provided 214 usage examples of this derivative, however, it did not provide a single example of its synonyms nuosaika and nuosaike.

The neologisms of other derivational categories are also used as synonyms of regular derivatives, for example, the nouns denoting persons derived from verbs (pabég-iuk-as (: pabégti), paklydž-iuk-as (: paklysti), dvok-ius (: dvokti) and the nouns derived from adjectives and noun (laisv-uol-is (: laisvas), tušt-ulis (: tuščias), mašin-orius (: mašina):

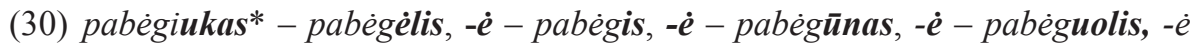
('refugee', 'war refugee'), 
(31) paklydžiukas* - paklydèlis, - $\dot{\boldsymbol{e}}$ ('the one who lost his way', 'lost'),

(32) dvokius* - dvokèlis ('stinker'),

(33) laisvuolis* - laisvūnas ('the one who is free'),

(34) tuštulis* - tuštuolis ('a narrow-minded man'),

(35) mašinorius* - mašinistas, - $\dot{\boldsymbol{e}}$ - mašininkas, - $\dot{\boldsymbol{e}}$ ('machinist').

All derivational neologisms could be replaced by cognitive derivatives and the meaning of the sentence remains the same, for example:

(36) Jis ir dabar <..> negalejo to dvokiaus pakęsti... A39 (cf. negalejo to dvokèlio pakęsti)

'He now <...> could not stand the stench',

(37) Žmogus, matyt, buvo arba visai kurčias, arba laisvuoliu apsimetus kiaulè... GD368 (cf. apsimetus laisvūnu)

'The man apparently was either completely deaf or pretended to be his own master',

(38) ...suvapejjo toksai traktoristas ne traktoristas, bet vis tiek kažkoks mašinorius, nes buvo apsivilkęs kombinezona A225 (cf. suvapejo mašininkas / mašinistas) '...mumbled a tractor-driver, as if a tractor-driver, but still a driver because he wore overalls'.

The usage of neologisms pabégiukas, paklydžiukas is probably occasional: they are created by analogy with the adjacent common Lithuanian derivative pamestinukas ('foundling'):

(39) Tapome pamestinukais, pabėgiukais, paklydžiukais K237

'We became foundlings, refugees, the lost'.

The interchange of neologisms and regular derivatives is unrestricted, cf. tapome pabégèliais, paklydèliais.

Sometimes a row of synonymous derivatives is extended by a new compound. For example, the second component of all compounds naming réksnys ('a loudmouth') is a noun gerkle ('a mouth'):

(40) praplèštgerklis* ${ }^{*}$ didžiagerklis - išverstgerklis / išverstagerklis ${ }^{5}$ paleistagerklis - plačiagerklis - verstagerklis ('a loudmouth', 'roarer').

A poor minded, sheepish man is named by the members of two synonym rows: the first synonym row includes compounds with kiaušas ('brainpan') as the second component:

(41) silpnakiaušis* - skystakiáušis - minkštakiáušis - papliùpkiaušis ('feebleminded', 'poor-minded'),

the derivatives of the second synonym row are based on the noun galva ('head'):

5 In synonym rows, slash divides derivational variants, i. e. the derivatives with the same base words and the same derivational affix but differ in secondary derivational means: joining, root vowels, etc. 
(42) kvaišgalvis* - asilgalvis - avigalvis - avelgalvis - avidgalva / avidgalvis avinagalvis / avingalvis - begalvis, $-\dot{e}$ - bobagalvis / bobgalvis - bukagalvis buriutgalvis ('fool' 'clot', 'mutt').

Replacing the neologisms with regular derivatives the meaning of the context remains essentially unchanged:

(43) Jisai sédèjo šalia, nors tasai praplèštgerklis ir spaudè ji A374 (cf.

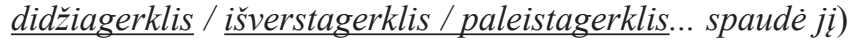

'He was sitting near, though the loudmouth pressed him',

(44) ...saujelès silpnakiaušiu žaidimas... K320 (cf. skystakiaušiu ) / minkštakiaušiu... žaidimas)

'...the game of some poor-minded people',

(45) Demokratinis pasaulis, kur kvaišgalviai sudaro dauguma, panašus $i$ méšlyna... KR190 (cf. asilgalviai / avigalviai / begalviai... sudaro dauguma) 'The democratic world where fools are in the majority is similar to a dunghill'.

Though the discussed noun neologisms and regular derivatives have a similar meaning, are used in a similar context and have a significant substitution possibilities, it could be admitted that the neologisms (at least for a certain period of time) are the part of specific lexicon. „This specificity (of the novel and noncustomary) is in itself a stylistic recourse.” (Rozenbergs 2004, 156)

Although there are more than 700 adjective derivational synonym rows in the current Lithuanian language (see Vaskelienè, Kučinskienè 2012a) and a lot of adjective neologisms are used in various texts (especially with the suffix -iškas, $-a$ ), they are not commonly used as synonyms of regular derivatives. However, such cases exist, for example, derivational synonym rows are extended by the neologisms with suffixes -lus, $i$, -iškas, $-a$, -uoklis, $-\dot{e}$ :

(46) duž-l-us, -i (: dužti) 'fragile', 'breakable', sting-l-us, -i (: stingti) 'stiff', pinklišk-as, -a (: pinklus) 'tangled', pašaip-uokl-is, -e (: pašaipa) 'mocking', 'sarcastic'.

These neologisms derived from adjectives supplement the rows of cognate derivatives fixed in dictionaries:

(47) dužlus, -i* - dužus, -i - dužnus, -i ('fragile', 'breakable'),

(48) stinglus, $-\boldsymbol{i}$ * - stingrus, $-\boldsymbol{i}$ - stingus, $-\boldsymbol{i}$ ('stiff'),

(49) pinkliškas, - $a^{*}$ - pinklinis, - $\dot{\boldsymbol{e}}-$ pinklus, -i ('tangled'),

(50) pašaipuoklis, - $\dot{\boldsymbol{e}}^{*}$-pašaipingas, -a-pašaipinis, $-\dot{\boldsymbol{e}}$-pašaipiškas, -a-pašaipus, $-\boldsymbol{i}$ ('mocking', 'sarcastic').

The derivational neologisms used instead of regular derivatives do not change the meaning of the sentence:

(51) Prieš šị dužlu stingluma VP 128 (cf. dužus / dužnus stinglumas)

'Against this breakable rigidity',

(52) labai stingliame ore dümai beveik nesisklaido VP 89 (cf. stingus / stingrus oras)

'smoke does not clear away in the stiff air', 
(53) ...netolies tikriausiai lankia pavojinga, pinkliška vieta... K168 (cf. pinkli / pinkline vieta)

'...there probably is a dangerous, tangled place near here',

(54) Visa jos praeitis - tèvu namai Gardine, jos pašaipuoklès seserys... SRII123124 (cf. pašaipiškos / pašaipinès / pašaipingos ${ }^{6}$ seserys).

'All her past is the parents' house in Grodno, her sarcastic sisters'.

The compounds formed with adjectives and nouns stambianosis, $\dot{e}$, prastakilmis, $-\dot{e}$ in dictionaries are presented only as nouns, but in the sources under investigation they are used as adjectives. So, the compounds with a noun nosis ('nose') as the second component and having similar meaning can be considered synonyms:

(55) stambianosis, $-\dot{e}^{*}-$ driūtanosis, $-\dot{e} /$ drūtanosis, $-\dot{e}-d r u ̄ k t n o s i s, ~-\dot{e}-$ kačergnosis, $-\dot{e}-$ stornosis, $-\dot{e} /$ storanosis, $-\dot{e}-$ tribianosis, $-\dot{e}$ ('the one with a big nose').

Two compounds with a noun kilme ('origin') also can be treated as synonyms: (56) prastakilmis, $-\dot{e}^{*}-$ žemakilmis ('the one of poor origin').

As the interchange of neologisms and regular compounds is possible without major restrictions, it can be stated that these are derivatives of high degree synonymy:

(57) ...aukšta stambianosè moteris žilstelejusiais plaukais... A400 (cf. driütanosé / stornose.... moteris)

'.... high woman with a big nose and grey hair',

(58) ...o prastakilmiai nugalètojai siautèjo kaip senovès barbarai... GD120 (cf. žemakilmiai nugalètojai)

'.. and the winners of poor origin were raging like ancient barbarians'.

Verb neologisms as synonyms of regular derivatives are used even more rarely, e. g., the verb pakiaulinti found in A. Čigriejus' text is used as a synonym of derivative prikiaulinti ('to make trouble for smb') fixed in the dictionaries:

(59) Pakiaulinti tai aš moku, oi, kaip aš moku... Č192 (cf. prikiaulinti tai aš moku)

'I know how to make trouble, oh, I know how...'.

Having checked the neologisms in The Corpus of the Contemporary Lithuanian Language it was found that it includes examples of the majority of derivational neologisms: sutelktis (40 usage cases), vienišystè (27), atpirktis (23), mašinorius (16), sukauptis (9), švogždesys (7), pereinamybe (4), skaudatis (4), stambianosis, $-\dot{e}$ (4), prastakilmis, -e (4), pakiaulinti (4), ieškesys (3), luošyste (3),

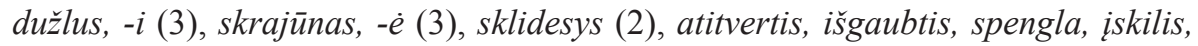
nuosaikybè, laisvuolis, tuštulis, kvaišgalvis, pinkliškas, -a (1 usage case of each), the derivatives tylesys, plastesys, igaubtis, stingla, gelsmas, mizantropyste, dvokius,

6 It should be said that some of these regular derivatives in the current Lithuanian language are rarely used: the corpus provides examples only with the adjective pašaipus, -i (396); while other adjectives are not common: pašaipingas, $-a$ (3), pašaipiškas, $-a$ (2); examples with the adjective pašaipinis, $-\dot{e}$ are not provided. 
pabégiukas, paklydžiukas, praplèštgerklis, silpnakiaušis, pašaipuoklis, -è are not fixed in the corpus.

\section{Conclusion}

1. The derivational neologisms found in the prose texts of Lithuanian authors can be considered to be synonyms of regular cognate derivatives: the derivatives are used in similar meaning and exhibit great substitution possibilities. The newly-formed derivational rows of synonyms complement the groups of derivational synonyms.

2. The majority of neologisms are potential derivatives: they obey the word formation rules, they are formed following the productive word formation types; some of them are formed by analogy.

3. Nouns are most commonly used as synonyms of regular derivatives; the majority of noun neologisms are the units of abstract lexicon (abstracts nouns formed with the suffixes -esys, -tis, $-y s t \dot{e},-y b \dot{e})$.

4. Neologisms are quite common in other texts: The Corpus of the Contemporary Lithuanian Language presented examples of 68 per cent of neologisms entering the rows of derivational synonyms. Their authorship is difficult to establish. Some neologisms could eventually be included in dictionaries and databases. Then the existing rows of derivational synonyms would become longer or new rows would be formed.

\section{Abbreviations}

A - Aputis, Juozas. Gegužè ant nulūžusio beržo

$\check{C}$ - Čigriejus, Algis. Ir parně̌e apynio kvapa

DD - Sabaliauskaite, Kristina. Danielius Dalba \& kitos istorijos

GD - Gutauskas, Leonardas. Daiktai

K - Kajokas, Donaldas. Lietaus migla Lu kalne

KE - Kajokas, Donaldas. Ežeras ir kiti ji lydintys asmenys

KR - Saja, Kazys. Kinivarpu raštai

LM - Šerelytè, Renata. Laukiniai mènesiai

$\mathrm{P}$ - Papievis, Valdas. Mes pasukome laikrodžius, ir atejo pavasaris

SRII - Sabaliauskaitè, Kristina. Silva Rerum II

$\mathrm{T}$ - Dabartinès lietuviu kalbos tekstynas

VP - Papievis, Valdas. Eiti

\section{Sources}

1. Aputis, Juozas. Gegužè ant nulūžusio beržo. Vilnius: Vaga, 1986.

2. Čigriejus, Algis. Ir parnešè apynio kvapa. Vilnius: Lietuvos rašytojų sajungos leidykla, 2011.

3. Sabaliauskaite, Kristina. Danielius Dalba \& kitos istorijos. [Vilnius]: Baltos lankos, 2012.

4. Gutauskas, Leonardas. Daiktai. Vilnius: Lietuvos rašytojų sajungos leidykla, 2008. 
5. Kajokas, Donaldas. Lietaus migla Lu kalne. Vilnius: Lietuvos rašytojų sajungos leidykla, 2002.

6. Kajokas, Donaldas. Ežeras ir kiti ji lydintys asmenys. Vilnius: Tyto alba, 2012.

7. Saja, Kazys. Kinivarpu raštai. Vilnius: Typoart, 2013.

8. Lietuvių kalbos žodyno papildymu kartoteka. 2015. Available: http://kiis.lki.lt/ antra-kartoteka [Date of access June, July 2016].

9. Šerelytė, Renata. Laukiniai mènesiai. Vilnius: Alma littera, 2006.

10. Lietuvių kalbos naujažodžiu duomenynas. Available: http://naujazodziai.lki.lt/ [accessed: June, July 2016].

11. Papievis, Valdas. Mes pasukome laikrodžius, ir atėjo pavasaris. Metai. 2015, no.08-09.Available: http://www.tekstai.lt/component/content/article/7988-valdaspapievis-mes-pasukome-laikrodzius-ir-atejo-pavasaris-apsakymas [Date of access 07.01.2016].

12. Sabaliauskaite, Kristina. Silva Rerum II. [Vilnius]: Baltos lankos, 2011.

13. Dabartinès lietuviu kalbos tekstynas. Available: http://tekstynas.vdu.lt/tekstynas/ [Date of access July, 2016].

14. Papievis, Valdas. Eiti. Vilnius: Lietuvos rašytojų sajungos leidykla, 2010.

\section{References}

1. Ambrazas, Vytautas (ed.). 2005. Dabartinès lietuviu kalbos gramatika. Vilnius: Mokslo ir enciklopedijų leidybos institutas.

2. Bauer, Laurie. 2004. The Function of Word-Formation and the InflectionDerivation Distinction. Aertsen, Words and their Places. A Festschrift for J. Lachlan Mackenzie. Henk, Hannay, Mike, Lyall, Rod (eds). Amsterdam: Vrije Universiteit, 283-292.

3. Keinys, Stasys (ed. in chief). 2006. Dabartinès lietuviu kalbos žodynas (šeštas (trečias elektroninis) leidimas). Vilnius: Lietuvių kalbos institutas.

4. Jakaitienè, Evalda. 2010. Leksikologija. Vilnius: Vilniaus universiteto leidykla.

5. Liutkevičienè, Danutè (ed. in chief). 2012-2017. Bendrinès lietuvių kalbos žodynas. Vilnius: Lietuvių kalbos institutas. Available: http://bkz.lki.lt/

6. Kniūkšta, Pranas. 1981. Rašytojas ir žodis. Vilnius: Mokslas.

7. Mikelionienè, Jurgita. 2002. Analogija žodžių daryboje. Potenciniai ir okaziniai dariniai. Acta Linguística Lituanica. 46, 73-80.

8. Miliūnaitè, Rita. 2015. Naujažodžių atranka ir pateikimas Lietuvių kalbos naujažodžių duomenyne. Leksikografija ir leksikologija. 5. Vilnius: Lietuvių kalbos institutas, $161-184$.

9. Naktinienè, Gertrūda (ed. in chief). 2005. Lietuviu kalbos žodynas (I-XX, 19412002): elektroninis variantas. Vilnius: Lietuvių kalbos institutas. Available: http:// www.lkz.lt/

10. Pakerys, Antanas. 1994. Akcentologija. I. Kaunas: Šviesa.

11. Pikčilingis, Juozas. 1975. Lietuviu kalbos stilistika. II. Vilnius: Mokslas.

12. Rozenbergs, Jānis. 2004. The Stylistics of Latvian. Rīga: LU Akadēmiskais apgāds.

13. Salys, Antanas. 1979. Neologisms in modern Lithuanian. Raštai 1. Bendrine kalba. Roma, 165-169.

14. Urbutis, Vincas. 2009. Žodžiu darybos teorija. Vilnius: Mokslo ir enciklopediju leidybos institutas. 
15. Vaskelienè, Jolanta. 2000. Darybiniai sinonimai. Šiauliai.

16. Vaskelienè, Jolanta. 2010. Lietuviu kalbos žodyne nefiksuoti dariniai ir jų funkcionavimas Antano Kalanavičiaus poezijoje. Filologija. 15. Šiauliai: Šiaulių universiteto leidykla, 151-166.

17. Vaskelienè, Jolanta. 2012. Žodynų nefiksuotų darinių funkcionavimas Ričardo Gavelio kūriniuose. Filologija. 17. Šiauliai: Šiaulių universiteto leidykla, 145-162.

18. Vaskelienè, Jolanta, Kučinskienè, Ramunè. 2012a. Dabartinès lietuvių kalbos būdvardžių darybiniai sinonimai. Žmogus ir žodis: didaktine lingvistika. 14 (1). Vilnius: Lietuvos edukologijos universitetas, 153-161.

19. Vaskelienè, Jolanta. 2017. Naujadarai Viktorijos Daujotytès tekstuose. Acta humanitarica universitatis saulensis. 23. Šiauliai: Šiaulių universiteto bibliotekos Leidybos skyrius, 149-170.

20. Župerka, Kazimieras. 2012. Stilistika. Šiauliai: Šiaulių universiteto leidykla.

21. Wales, Katie. 1989. A Dictionary of Stylistics. London and New York: Longman.

\section{Kopsavilkums}

Lietuviešu valodā pastāvīgi rodas jauni atvasinājumi: vieni nosauc jaunas lietas, jēdzienus, savukārt citi tiek lietoti kā sistēmisko vārdu sinonīmi. Lietuviešu valodā ir daudz derivatīvo sinonīmu - atvasinājumu, kuriem ir kopīga sakne, atšksirīgi vārddarināšanas formanti un līdzīga leksiskā nozīme. Derivatīvo sinonīmu rindas nav statiskas: tās zūd vai kḷūst îsākas, ja zūd atvasinājums vai tā nozīme, rodas vai kḷūst garākas, ja rodas jauni atvasinājumi vai jauna atvasinājuma nozīme. Pētījuma materiāls - lietuviešu autoru tekstos (izņemot dzeju) konstatētie jaunie atvasinājumi, kuri tiek lietoti kā sistēmisko atvasinājumu sinonīmi. Rakstā aplūkotas no jauna radušās vai garākas kḷuvušas derivatīvo sinonīmu rindas un tiek analizēta jauno atvasinājumu darināšana, lietošanas tendences, substitūcijas iespējas.

Materiāla analīze ḷauj izdarīt šādus secinājumus:

1. Lietuviešu autoru tekstos konstatētos jaunos atvasinājumus var uzskatīt par sistēmisko kopīgas saknes atvasinājumu sinonīmiem: atvasinājumi tiek lietoti līdzīgā nozīmē, un tiem piemît lielas substitūcijas iespējas. No jauna radušās derivatīvo sinonīmu rindas papildina sistēmisko derivatīvo sinonīmu grupas.

2. Vairums jauno atvasinājumu ir potenciāli atvasinājumi: tie atbilst vārddarināšanas tendencēm, ir darināti atbilstoši produktīviem derivācijas tipiem, daži no tiem - pēc analoǵijas.

3. Kā sistēmisko atvasinājumu sinonīmi galvenokārt tiek lietoti lietvārdi; lielākā daļa jauno lietvārdu atvasinājumu ir abstraktas leksikas vienības (verbālie un nominālie abstrakti ar izskaņām -esys, -tis, -ysté, -ybè).

4. Jaunie atvasinājumi samērā bieži tiek lietoti dažādos tekstos: Mūsdienu lietuviešu valodas tekstu korpusā konstatēti 68\% derivatīvo sinonīmu rindu piemēri, kuras veido jaunie atvasinājumi. To autorība ir grūti nosakāma. Atsevišķi jaunie atvasinājumi ar laiku varētu tikt ieklauti vārdnīcās vai datubāzēs. Tādā gadījumā kḷūtu garākas esošās sistēmiskās derivatīvo sinonīmu rindas vai veidotos jaunas. 